\title{
従動力とみなされる軸方向流体力を受ける弾性はりの動的安定性*
}

藤田 勝久 ${ }^{* 1}$, 後藤 彰秀 $^{* 2}$, 川合 忠雄 ${ }^{* 1}$

\section{Dynamic Stability of an Elastic Beam Subjected to Axial Fluid Forces Considered to be Follower Forces}

\author{
Katsuhisa FUJITA ${ }^{* 1}$, Akihide GOTOU and Tadao KAWAI \\ ${ }^{* 1}$ Osaka City Univ., Mechanical \& Physical Engineering, Graduate School of Engineering \\ 3-3-138, Sugimoto, Sumiyoshi-ku, Osaka, 558-8585, Japan
}

The stability of nonconservative system of a beam is investigated when an elastic beam is subjected to follower forces. The mathematical formulations for a conservative system and a nonconservative system are established regarding to a uniform cantilever subjected to a concentrated force and a uniform distributed force axially. The displacement of a uniform cantilever is assumed to be obtained by superposing the modal functions which are normal modes in a vacuum, and is estimated by applying the Galerkin method. Changing the forces, the eigenvalue analysis is performed, and the root locus is calculated for the stability analysis. And, the relationships between forces and frequencies for the undamped system and the damped system of the uniform cantilever subjected to a concentrated force and a uniform force are investigated. When the system is subjected to a conservative force, the divergence phenomenon is confirmed to appear first. On the other hand, when the system is subjected to a nonconservative force such as follower force, the flutter phenomenon is confirmed to appear first although the critical force becomes high. And, by changing the structural damping, the destabilized effect due to the structural damping is confirmed when an elastic beam is subjected to follower forces. Moreover, the dynamic behaviors of the higher modes, and the stability of a simply supported beam and a free-free beam are also studied.

Key Words : Axial Force, Follower Force, Nonconservative Elastic Stability, Flutter, Divergence

\section{1. 緒言}

機械や構造物の大形化や軽量化に伴い，その動的な安定問題がますます重要視されるようになってきている. 従来の動的な安定性解析では，多くの場合外力が保存力として扱われる保存系である. しかし，航空宇宙構造物 から海洋構造物における空気や水などの流体力を受ける場合については, 非保存力（従動力）としての取り扱い の検討も重要である.

非保存力（従動力）の研究は比較的古くからすでに問題の提起がなされてきており(1)-(4)，さらに引き続いてい くつかの研究がなされてきているが(5)-(9), 必ずしも十分とはいえない. すでに, 筆者らも片持ちはりの 2 自由度系 の離散化モデルにより非保存力（従動力）の検討 ${ }^{(10)}$ を報告してきた. そこでは, 保存力モデルとして Euler model, 非保存力（従動力）モデルとして Herrmann model を導入し，集中荷重を先端に作用させたときの系の安定性を報 告した. また, 非保存力（従動力）が作用したときに生じるフラッタ現象について, 減衰の不安定効果やフラッ 夕挙動が連成モードフラッタや単独モードフラッタになることを示した. さらに，2 自由度モデルと連続体モデ ルとの間の物理的整合性について考察した。

ここでは, 軸流を受けるはりについて, 流体力を軸方向力とみなして, 軸方向分布荷重が弾性はりに作用する場

\footnotetext{
* 原稿受付 2012 年 10 月 18 日

*1 正員, フェロー, 大阪市立大学大学院工学研究科機械物理系

（干558-8585 大阪府大阪市住吉区杉本 3-3-138）

*2 学生員, 大阪市立大学大学院工学研究科機械物理系 (現タカラベルモント (株))

E-mail: fujita@mech.eng.osaka-cu.ac.jp
} 


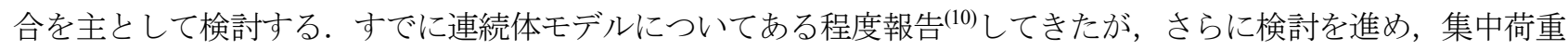
と分布荷重との間での不安定挙動の相違の有無, 減衰の不安定効果, 連成モードフラッタと単独モードフラッタ の考察，さらに高次モードの安定性や弾性はりの支持条件の影響についても考察する.

\section{2. 理 論}

\section{$2 \cdot 1$ 保存系と非保存系のモデリング}

構造物に作用する流体力としての抗力は，摩擦抗力と圧力抗力に分けられる．流体が構造物の表面を流れると き, 構造物は流体から粘性のために摩擦による抗力を受ける. 構造物が流線形の場合この摩擦による力が支配的 になる. さらに，構造物の表面からの渦や剥離などにより，構造物は流体から圧力差に基づく抗力を受ける. 流 線形でないときこの圧力による力が支配的になる.

ここでは，一様弾性はりに上述の流体力が作用するとき，はりに作用する軸方向の成分に着目して，弾性はり の安定問題を考察する．これらの流体力を集中荷重と一様分布荷重で近似して，これらが作用する際の構造の弾 性安定問題を考える. まず, 一般的なはりの弾性安定問題として, 図 1 に示寸片持ちはりモデルを考える.

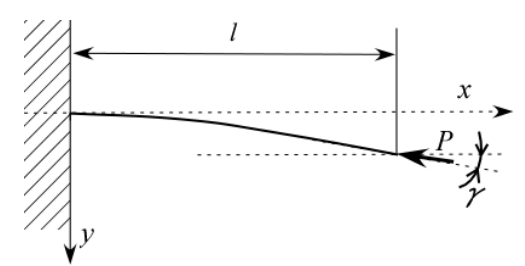

(a) Concentrated load

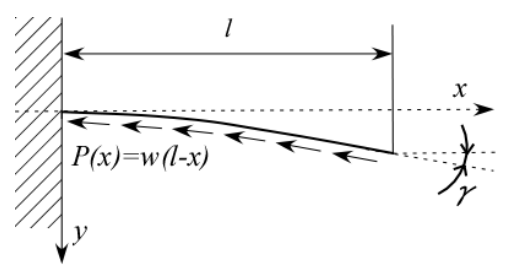

(b) Distributed load

Fig. 1 Modeling on elastic stability of structure

ここで, $l$ ははりの長さ, $P, P(x)$ は, 各々, 軸方向または接線方向の集中荷重と一様分布荷重を示す. 非保存力 （従動力）の場合, 集中軸力または分布軸力である. また， $w$ ははりの単位長さあたりの接線方向の分布荷重を 示す. $\gamma$ は荷重の作用する角度を示す.

図 1 (a) は自由端に集中荷重が作用寸る場合で, $\gamma=0$ の場合は保存力が作用寸るモデルとして Euler の問題に 対応する.この $\gamma=0$ の場合は静力学のはりの Euler 座屈である. また, $\gamma>0$ の場合は非保存力（従動力）が作 用する場合である. 一方, 図 1 (b) は接線方向の一様分布荷重が作用寸る場合であり， $\gamma=0$ の場合ははりがたわ む前の状態の軸方向に作用する一様分布荷重となり，保存力が作用する場合となる. また， $\gamma>0$ の場合ははりの 接線方向に従動力として作用する一様分布荷重となり, 非保存力（従動力）が作用する場合となる. なお, 図 1 (a) を 2 自由度の離散化モデルで表現するとき, 保存力が作用する場合は Euler モデル, 従動力である非保存力が作 用する場合は, Herrmann モデルとなる(10).

\section{$2 \cdot 2$ 支配方程式}

\section{$2 \cdot 2 \cdot 1$ 連続体モデルの先端に集中荷重が作用する場合}

図 1 (a) の片持ちはりモデルに集中荷重 $P$ が作用するとき, $P$ が保存力の場合は Euler 座屈問題となり, 次式 が得られる.

$$
P_{c r}=\frac{\pi^{2} E I}{(2 l)^{2}}
$$

ここで， $P_{c r}$ は座屈荷重である.

次に, 非保存力（従動力）の集中荷重 $P$ が作用するときは, 


$$
\rho A \frac{\partial^{2} y}{\partial t^{2}}+E I \frac{\partial^{4} y}{\partial x^{4}}+P \frac{\partial^{2} y}{\partial x^{2}}+c \frac{\partial y}{\partial t}=0
$$

となる.ここで，材料減衰や構造減衰による減衰項は第 4 項で表現できるとしている.

このような集中荷重は，例えば軸流中のはりでは流体から受ける圧力抗力や摩擦抗力を，はりの先端に近似的 に集中させる場合や，流体が弾性管の先端より噴出する場合などが考えられる.

\section{$2 \cdot 2 \cdot 2$ 連続体モデルの片持ちはりに一様分布荷重が作用する場合}

図 1 (b) のような片持ちはりモデルに軸方向の一様分布荷重 $w$ が作用するときの支配方程式は, 保存力の場 合, 軸力 $P(x)=w(l-x)$ であるので, 次式が得られる.

$$
\rho A \frac{\partial^{2} y}{\partial t^{2}}+E I \frac{\partial^{4} y}{\partial x^{4}}+w(l-x) \frac{\partial^{2} y}{\partial x^{2}}-w \frac{\partial y}{\partial x}+c \frac{\partial y}{\partial t}=0
$$

次に，片持ちはりモデルに接線方向に一様分布荷重 $w$ が作用するときの支配方程式は，非保存力（従動力） の場合は

$$
\rho A \frac{\partial^{2} y}{\partial t^{2}}+E I \frac{\partial^{4} y}{\partial x^{4}}+w(l-x) \frac{\partial^{2} y}{\partial x^{2}}+c \frac{\partial y}{\partial t}=0
$$

となる.

このような一様分布荷重は, 例えば軸流中のはりでは流体から受ける表面における摩擦に起因する摩擦抗力が 主体と考えられる.

\section{$2 \cdot 3$ 数值解法}

上述の支配方程式の解を得るために実施した数值解法について, 前報(10)でも説明したが概略を述べる. 集中荷 重が作用する場合と分布荷重が作用寸る場合とで, 支配方程式は少し異なるが，数值解析の手順は同じなので, 一様片持ちはりに分布荷重の非保存力（従動力）が作用する場合を取り上げて述べる.

まず, 一様片持ちはりの変位 $y(x, t)$ を, Galerkin 法を応用するため, 境界条件を満足する関数 $\phi_{i}(x)$ の級 数展開で表されるとする.

$$
y(x, t)=\sum_{i=1}^{\infty} \phi_{i}(x) q_{i}(t)
$$

ここで， $\phi_{i}(x)$ は一様片持ちはりの境界条件を満足しなければならない．また， $q_{i}(t)$ は時間関数である.

そして, 例えば, 一様片持ちはりに非保存力（従動力）の接線方向の一様分布荷重が作用寸る場合の支配方程 式である式 (4) に，式 (5) を代入すると，

$$
\rho A \sum_{i=1}^{\infty} \phi_{i}(x) \ddot{q}_{i}(t)+E I \sum_{i=1}^{\infty} \frac{d^{4} \phi_{i}(x)}{d x^{4}} q_{i}(t)+w(l-x) \sum_{i=1}^{\infty} \frac{d^{2} \phi_{i}(x)}{d x^{2}} q_{i}(t)+c \sum_{i=1}^{\infty} \phi_{i}(x) \dot{q}_{i}(t)=0
$$


となる. いま, 固有関数の $\phi_{i}(x)$ として, 真空中の一様片持ちはりの固有関数を採用すると,

$$
\frac{d^{4} \phi_{i}(x)}{d x^{4}}-\kappa_{i}^{4} \phi_{i}(x)=0
$$

を満足する. ここで, $\kappa_{i}^{4}=\frac{\rho A}{E I} \omega_{i}{ }^{2}$ であり， $\omega_{i}$ は固有関数 $\phi_{i}(x)$ に対応する固有円振動数である. 式 (7) の 関係を式 (6) に適用して整理すると,

$$
\sum_{i=1}^{\infty} \phi_{i}(x) \ddot{q}_{i}(t)+\frac{c}{\rho A} \sum_{i=1}^{\infty} \phi_{i}(x) \dot{q}_{i}(t)+\left\{\sum_{i=1}^{\infty} \omega_{i}^{2} \phi_{i}(x) q_{i}(t)+\frac{w(l-x)}{\rho A} \sum_{i=1}^{\infty} \frac{d^{2} \phi_{i}(x)}{d x^{2}} q_{i}(t)\right\}=0
$$

となる. そして, 式 (8) の両辺に固有円振動数 $\omega_{k}$ を持つ固有関数 $\phi_{k}(x)$ をかけて，はり全長にわたって 0 から $l$ まで積分し, 固有関数の直交性を利用すると,

$$
\begin{aligned}
& \left\{\int_{0}^{l} \phi_{k}^{2}(x) d x\right\} \ddot{q}_{k}(t)+\left\{\frac{c}{\rho A} \int_{0}^{l} \phi_{k}^{2}(x) d x\right\} \dot{q}_{k}(t) \\
& +\left\{\omega_{k}^{2}\left(\int_{0}^{l} \phi_{k}^{2}(x) d x\right) q_{k}(t)+\sum_{i=1}^{\infty}\left(\frac{w}{\rho A} \int_{0}^{l}(l-x) \phi_{k}(x) \frac{d^{2} \phi_{i}(x)}{d x^{2}} d x\right) q_{i}(t)\right\}=0 \quad(k=1 \sim \infty)
\end{aligned}
$$

となる. ここで, モードの打ち切りを $n$ とすると， $k=1 \sim n$ となる. 式 (9) をマトリックス表示で書き直す と,

$$
\left[\begin{array}{lll}
\ddots & & 0 \\
& M_{k} & \\
0 & & \ddots
\end{array}\right]\left\{\ddot{q}_{k}(t)\right\}+\left[\begin{array}{ccc}
\ddots & & 0 \\
& C_{k} & \\
0 & & \ddots
\end{array}\right]\left\{\dot{q}_{k}(t)\right\}+\left(\left[\begin{array}{ccc}
\ddots & & 0 \\
& K_{k} & \\
0 & & \ddots
\end{array}\right]+\left[D_{i, k}\right]+\left[E_{i, k}\right]\left\{q_{k}(t)\right\}=0\right.
$$

となる.ここで，

$$
\begin{aligned}
& M_{k}=\int_{0}^{l} \phi_{k}^{2}(x) d x \\
& C_{k}=\frac{c}{\rho A} \int_{0}^{l} \phi_{k}^{2}(x) d x \\
& K_{k}=\omega_{k}^{2} \int_{0}^{l} \phi_{k}^{2}(x) d x \\
& D_{i, k}=\frac{w l}{\rho A} \int_{0}^{l} \phi_{k}(x) \frac{d^{2} \phi_{i}(x)}{d x^{2}} d x \\
& E_{i, k}=\frac{-w}{\rho A} \int_{0}^{l} x \phi_{k}(x) \frac{d^{2} \phi_{i}(x)}{d x^{2}} d x
\end{aligned}
$$

である. 式 (10) において一様分布荷重 $w$ を変化させて, 複素固有值解析を行い, 根軌跡を求める. 固有值 $\lambda$ の $\operatorname{Re}(\lambda)$ が正で, $\operatorname{Im}(\lambda) \neq 0$ のとき, 振動状態はフラッタとなる. また, $\operatorname{Re}(\lambda)$ が正で, $\operatorname{Im}(\lambda)=0$ のとき, 
振動状態はダイバージェンスとなる，そして，上記では非保存力（従動力）として接線方向の一様分布荷重が作用 する場合である式 (4) について取り扱ったが, 非保存力（従動力）として集中荷重が作用する場合である式 (2), 保 存力として軸方向の一様分布荷重が作用する場合である式 (3) についても同様の取り扱いにより, 解が得られる.

\section{3. 解析結果と考察}

\section{$3 \cdot 1$ 数値計算の諸元}

数值計算するはりの物理定数を表 1 に示す. ヤング率は銅に相当する值を用いた．実験等をすることを考えて 無次元化はしていない.

Table 1 Specifications of a beam

\begin{tabular}{|c|c|c|c|}
\hline$\rho:$ Density $\left[\mathrm{kg} / \mathrm{m}^{3}\right]$ & $8.92 \times 10^{3}$ & $R:$ Radius of beam $[\mathrm{m}]$ & $1.00 \times 10^{-3}$ \\
\hline$E$ : Young modulus $[\mathrm{Pa}]$ & $1.00 \times 10^{11}$ & $l:$ Length of beam $[\mathrm{m}]$ & 1.00 \\
\hline
\end{tabular}

\section{$3 \cdot 2$ 連続体モデルである片持ちはりに集中荷重(保存力)が作用する場合}

片持ちはりに集中荷重(保存力)が作用する場合は，いわゆる集中荷重による構造力学の Euler 座屈である. 2 ・ 2・1節の式 (1) を用いて座屈荷重を算出すると, $P_{c r}=0.18$ となる. また, これは 2 自由度系の離散化モデルの Euler model に対応する(10).

\section{$3 \cdot 3$ 連続体モデルである片持ちはりに集中荷重(非保存力)が作用する場合}

従動力である非保存力の集中荷重が作用する連続体モデルの片持ちはりの場合は，2 自由度系の離散化モデル の Herrmann model に対応する(10). 図 2 に非減衰系と減衰系についての根軌跡を示寸. 非減衰の場合は, 根軌跡の 代わりに荷重と固有円振動数の関係を示す．また，図 3 に減衰比を変化させて, 集中荷重と根軌跡の実部との関 係を示す. なお，図 2 (a) の曲線が縦軸と交差する值は, 荷重が零のときの連続体モデルの 1 次と 2 次の固有円振 動数を示す.

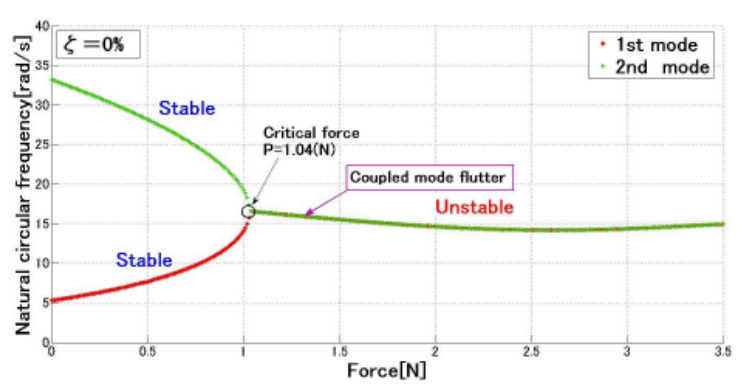

(a) No damping

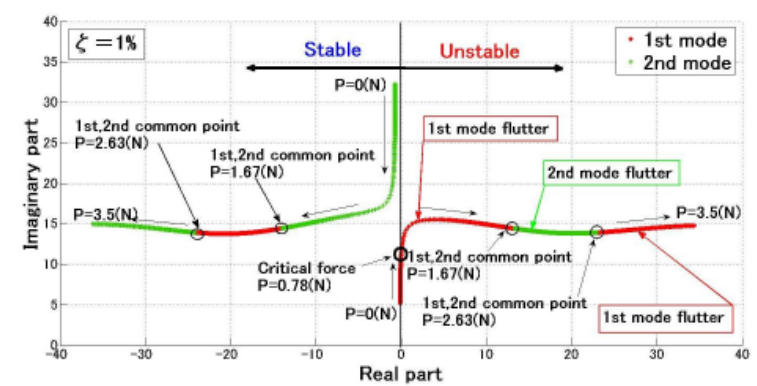

(b) $1 \%$ critical damping

Fig. 2 Continuous model (cantilever) subjected to nonconservative concentrated force 


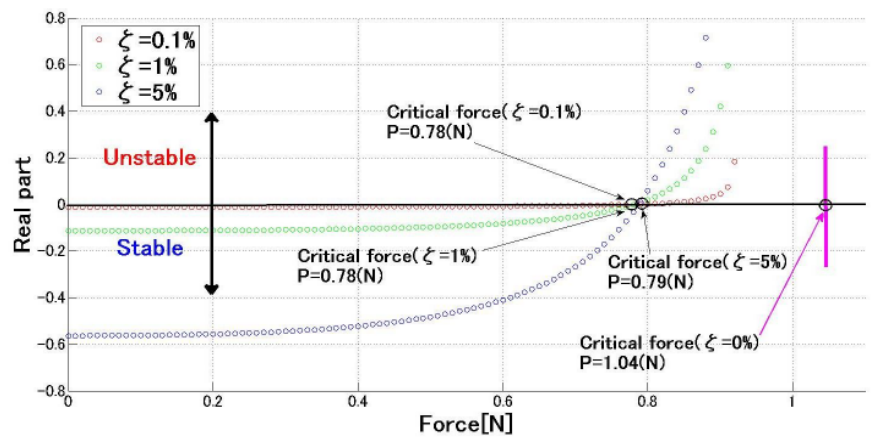

Fig. 3 Effect of damping on instability of continuous model (cantilever) subjected to nonconservative concentrated force

図3は，減衰比をパラメータにして力（荷重）を増やすに従って，系の実部が安定である負の領域から不安定で ある正の領域になる経緯を示している. 減衰があるときの系の臨界荷重は $P=0.79 \mathrm{~N}$ 前後であり, 減衰がないと きは $P=1.04 \mathrm{~N}$ である. すなわち, 非保存力が作用する系では系の減衰の存在が臨界荷重を低下させ, 不安定効 果を与えることがわかる. 同様に, このことをさらに考察するため, 図4に連続体モデルに集中荷重の非保存力 (従 動力）が作用する系のフラッタについて, 減衰を変化させて, 臨界荷重と虚部の関係を検討する. 横軸は荷重を, 縦軸は固有円振動数を表す根軌跡の虚部を示す. 図4と図2 (a) とを併せて観察すると, 非減衰系の場合は, 1次モ ードと2次モードが合体し，連成モードフラッタが発生している. 減衰系の場合は，作用する力を増加させると 1 次モードの途中で単独モードフラッタが現れることがわかる．この単独フラッタの荷重は無減衰系の連成モード フラッタより低くなっている. 作用する力がさらに増加したところで, 1次と2次のモードは合体を繰り返すこと がわかる，しかし，この合体する荷重は無減衰系の合体する荷重より高くなっている.

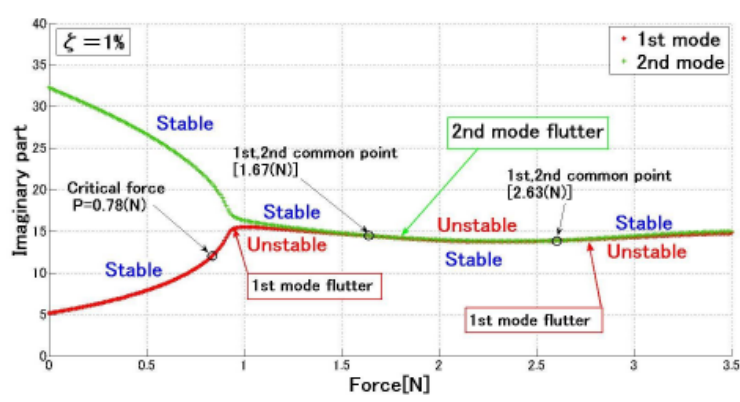

(a) $1 \%$ critical damping

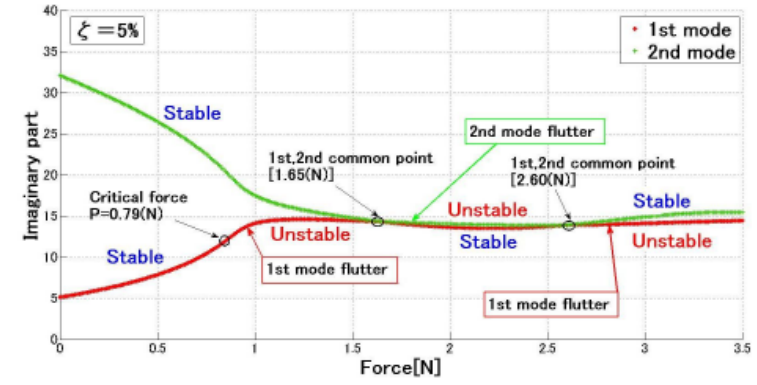

(b) $5 \%$ critical damping

Fig. 4 Effect of critical force on flutter of continuous model (cantilever) subjected to nonconservative concentrated force

また，集中荷重が作用したときのモードの変化をフラッタの発生前後で比較すると図 5, 6 となる. なお，これ らの連続体モデルでの数值計算のモードの打ち切りの次数は, 10 とした. これ以降に示す数值計算においても同 様である. 


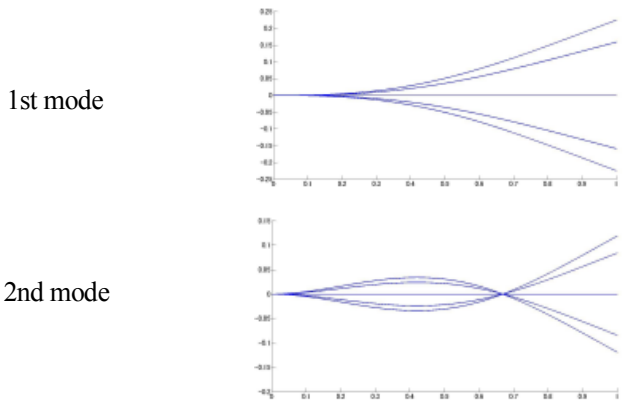

(a) Stable, $P=0.7 \mathrm{~N}$

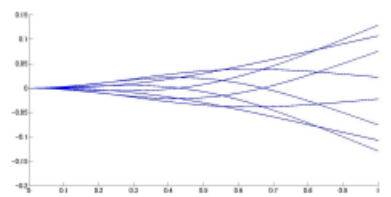

(b) Unstable (flutter), $\quad P=1.2 \mathrm{~N}$

Fig. 5 Mode shape before and after coupled mode flutter of continuous model (cantilever) subjected to nonconservative concentrated force (Undamped system)

1st mode

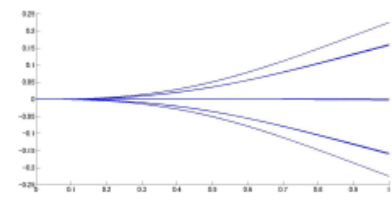

(a) Stable, $P=0.7 \mathrm{~N}$

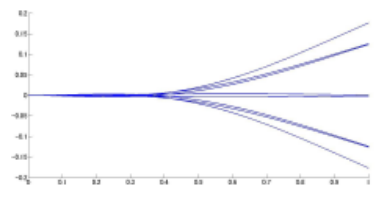

(b) Unstable (flutter), $\quad P=0.9 \mathrm{~N}$

Fig. 6 Mode shape before and after single mode flutter of continuous model (cantilever) subjected to nonconservative concentrated force (Damped system, $1 \%$ of critical damping)

\section{$3 \cdot 4$ 連続体モデルである片持ちはりに一様分布荷重(保存力)が作用する場合}

連続体モデルに一様分布荷重(保存力)が作用する場合は，いわゆる構造力学の一様分布荷重による Euler 座屈 である．その弾性挙動は容易に予測されるが，後述する従動力である非保存力が作用する場合と比較するため, 図 7 に非減衰系と減衰系に関して, その根軌跡を示寸. なお, 非減衰系の場合は根軌跡の代わりに横軸の荷重と縦 軸の固有円振動数の関係を示した. また, 図 8 に, 減衰比を変化させて, 分布荷重と安定, 不安定を支配する根 軌跡の実部との関係を示す．なお，非保存力（従動力）の場合，軸力が安定性に関して重要であるので，分布荷 重が作用する場合も集中荷重と同じ荷重レベルを用いて安定限界を考察することにする. 図 7 以降の分布荷重に 関する図の横軸は, 力（荷重）として表現し，図 1 (b) の $x=0$ の位置の $P(0)=w l$ の值を示している. これを改 めて $P$ と表現する.

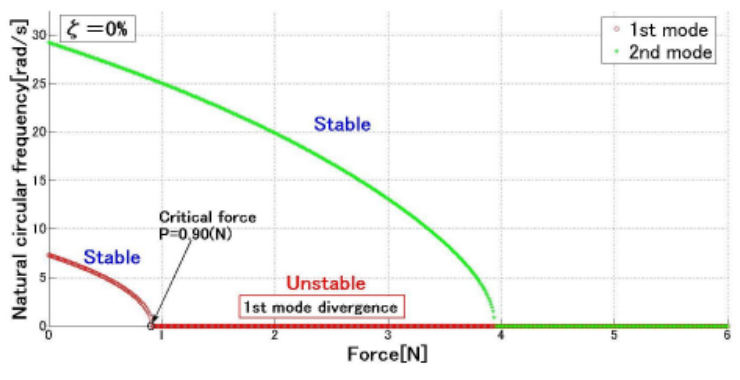

(a) No damping

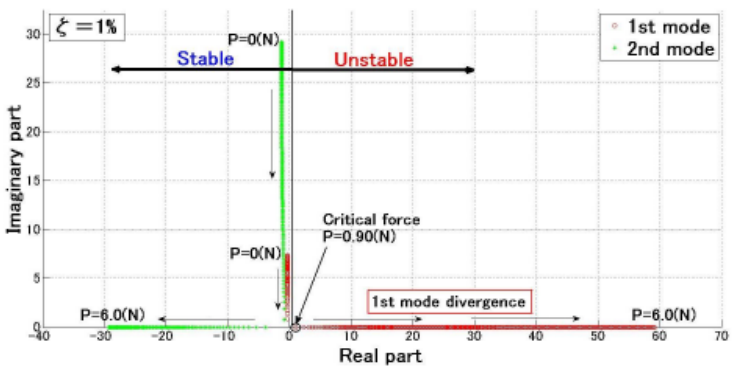

(b) $1 \%$ critical damping

Fig. 7 Continuous model (cantilever) subjected to conservative distributed force 


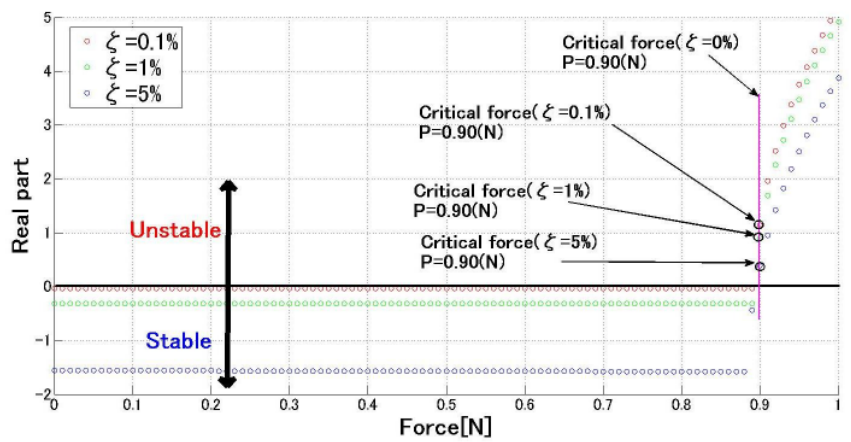

Fig. 8 Effect of damping on instability of continuous model (cantilever) subjected to conservative distributed force

\section{$3 \cdot 5$ 連続体モデルである片持ちはりに一様分布荷重(非保存力)が作用する場合}

従動力である非保存力の一様分布荷重が，はりの接線方向に作用寸る場合に関して，図 9 に非減衰系と減衰系 についての根軌跡を示す. 同じく非減衰の場合は, 根軌跡の代わりに荷重と固有円振動数の関係を示寸. 図 8 と同 様に, 図 10 に, 減衰比を変化させて, 分布荷重と根軌跡の実部との関係を示寸.

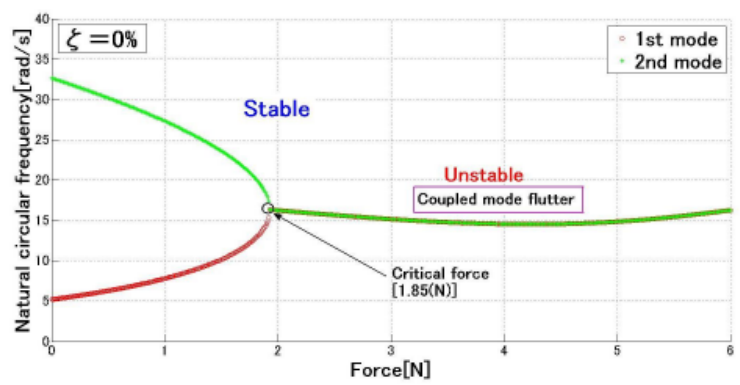

(a) No damping

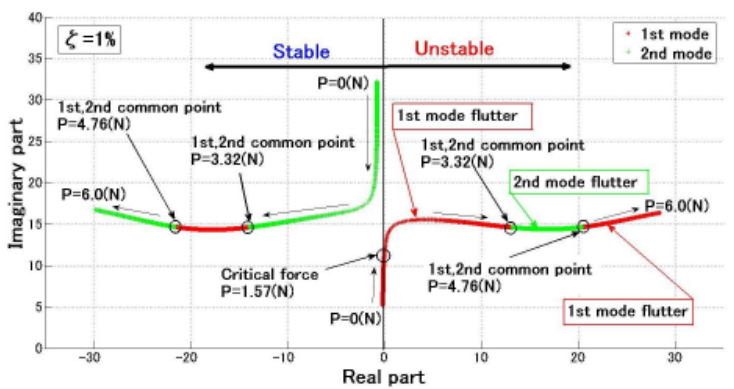

(b) $1 \%$ critical damping

Fig. 9 Continuous model (cantilever) subjected to nonconservative distributed force

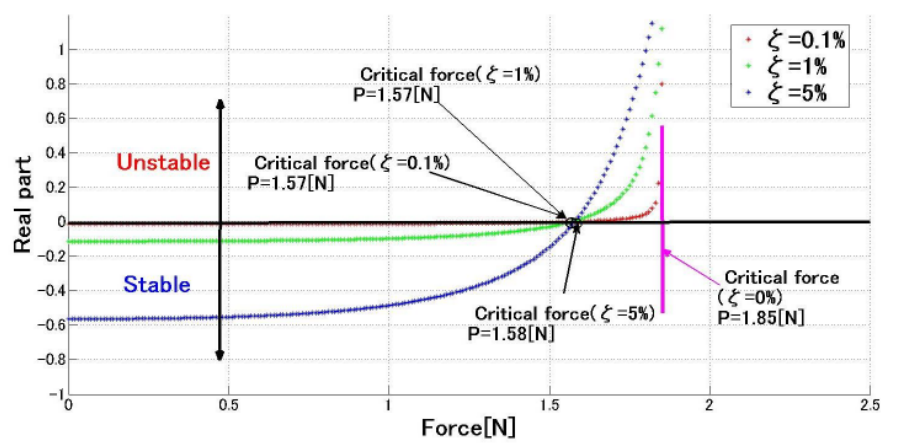

Fig. 10 Effect of damping on instability of continuous model (cantilever) subjected to nonconservative distributed force

図 8 と図 10 を比較すると, 非保存力（従動力）が作用する系では系の減衰の存在が不安定効果を与えることが わかる．同様に，このことをさらに考察するため，図 11 に連続体モデルに分布荷重の非保存力が作用する系のフ ラッタについて, 減衰を変化させて, 臨界荷重と虚部の関係を検討する. 横軸は荷重を, 縦軸は固有円振動数を 表す根軌跡の虚部を示す. 図 11 と図 9 (a) とを併せて観察すると, やはり，非減衰系の場合は，1次モードと 2 次モードが合体し，連成モードフラッタが発生しているが，減衰系の場合は，1 次モードの途中で単独モードフ ラッタが現れ, 連成モードフラッタの荷重より低い. さらに力を増加させると, 1 次モードと 2 次モードとが合 
体をし，さらに，交互に不安定になることがわかる．また，合体する荷重は無減衰系より高い，作用する荷重が 集中荷重の場合と一様分布荷重の場合とで, 動的挙動の変化にほとんど差がないことがわかる.

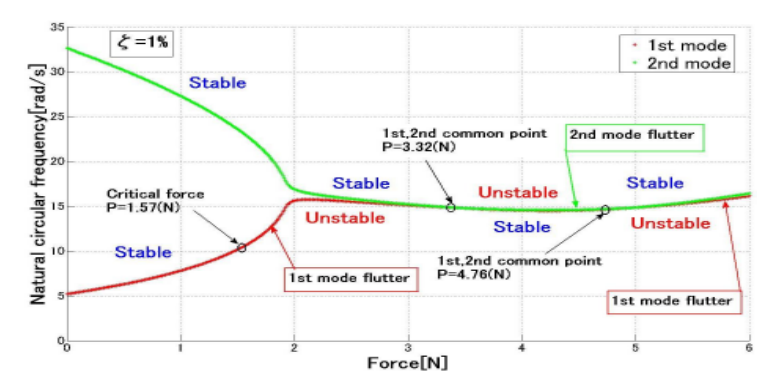

(a) $1 \%$ critical damping

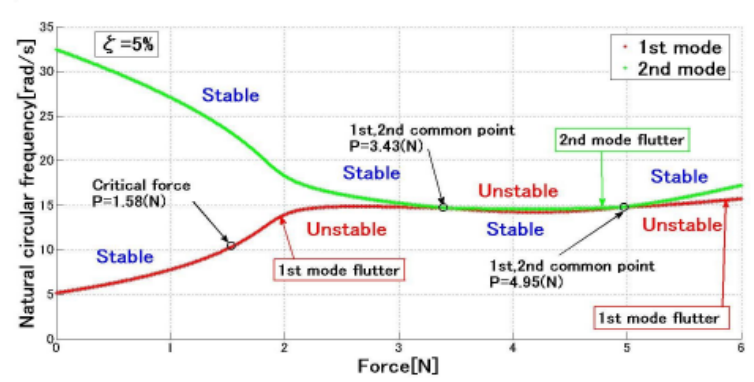

(b) $5 \%$ critical damping

Fig. 11 Effect of critical force on flutter of continuous model (cantilever) subjected to nonconservative distributed force

また，分布荷重が作用するときのモードの変化をフラッタの発生前後で比較すると図 12,13 となる. 片持ち はりに従動力である非保存力として, 集中荷重が作用した場合と一様分布荷重が作用した場合についての臨界荷 重前後の振動モード形は, 非減衰系の場合は図 5 と図 12 との比較により, 両者の間にほとんど相違は認められな い. また, 減衰系の場合においても, 図 6 と図 13 との比較より, 同様に両者の相違はほとんど認められないこと がわかる。

このように，弾性片持ちはりに，非保存力（従動力）がはりの先端に集中荷重として作用しても，はり全体に 一様荷重として作用しても同じ挙動を示すことがわかる. 流体がフレキシブルホースの先端から比較的速い流速 で吹き出したときの先端の流体反力によるホースのふれ回り挙動は周知のことであるが，弾性はり全体に流体の 摩擦抗力や圧力抗力の接線方向成分が作用寸るときにも, 同様の挙動が生じることになると考えられる.

1st mode

2nd mode
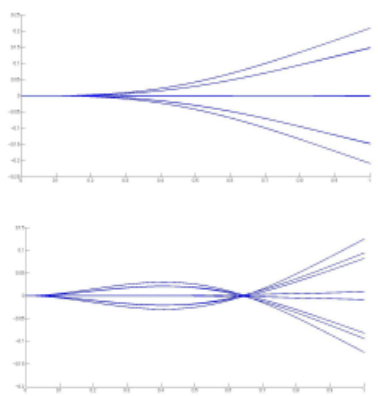

(a) Stable, $w=1.7 \mathrm{~N} / \mathrm{m}$

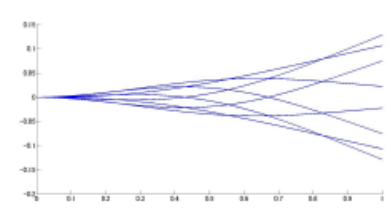

(b) Unstable (flutter), $\quad w=2.0 \mathrm{~N} / \mathrm{m}$

Fig. 12 Mode shape before and after flutter of continuous model (cantilever) subjected to nonconservative distributed force (Undamped system)

1st mode

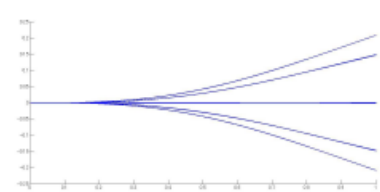

(a) Stable, $w=1.4 \mathrm{~N} / \mathrm{m}$

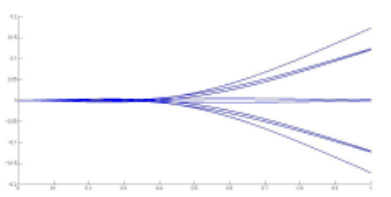

(b) Unstable (flutter), $\quad w=1.7 \mathrm{~N} / \mathrm{m}$

Fig. 13 Mode shape before and after single mode flutter of continuous model (cantilever) subjected to nonconservative distributed force (Damped system, 1\% of critical damping) 


\section{$3 \cdot 6$ 片持ちはりの高次振動の動的安定性}

いままで, 片持ちはりが従動力を受ける場合の低次振動の 1 次, 2 次振動の動的安定性について考察してきた. ここでは, さらに高次の振動について検討する.

図 14 (a), (b) に片持ちはりに一様分布荷重（保存力）が作用するときの非減衰系と $1 \%$ 減衰系について，分布 荷重と固有円振動数, または根軌跡の虚部の関係を示す。一方，図 15 (a), (b) は非保存力（従動力）が作用する 場合の非減衰系と $1 \%$ 減衰系について, 同じく分布荷重と固有円振動数，または根軌跡の虚部の関係を示寸.

片持ちはりに一様分布荷重 (保存力) が作用するときは, 減衰の影響はほとんど無くて, 高次モードも Euler 座 屈の挙動を順次示すことがわかる，一方，非保存力（従動力）の一様分布荷重が作用するときは，非減衰系のと きは 3 次と 4 次モード， 5 次と 6 次モードが各々合体して連成モードフラッタに順次なることがわかる.さらな る高次振動も同様である. また, 減衰系のときは, 3 次モードおよび 5 次モードの途中で単独モードフラッタが 現れることがわかる. それから作用寸る力がさらに増加したところで, 3 次は 4 次と, 5 次は 6 次とモードの合体 を繰り返す。このことも，さらなる高次振動において同様であると考えられる.ささらに，高次振動においても減 衰の不安定効果が認められる.

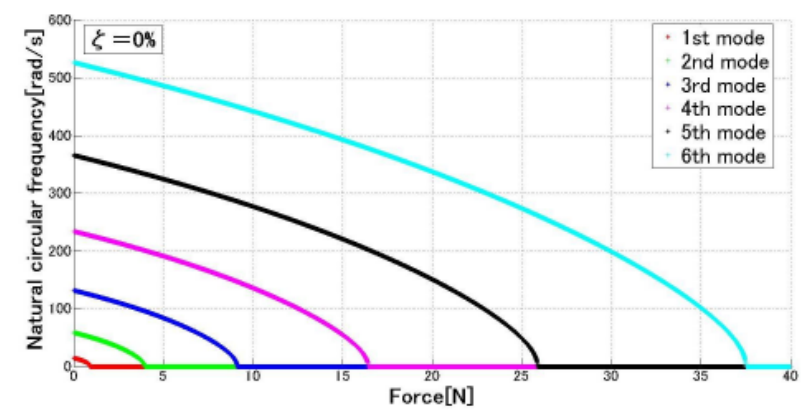

(a) No damping

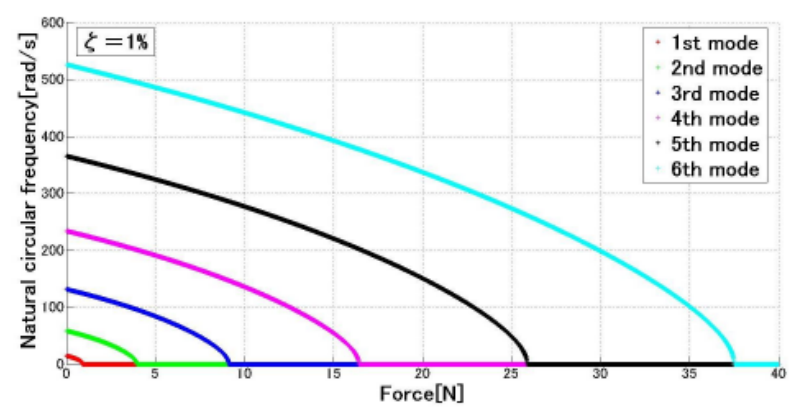

(b) $1 \%$ critical damping

Fig. 14 Dynamic stability of higher mode of a continuous model (cantilever) subjected to conservative distributed force

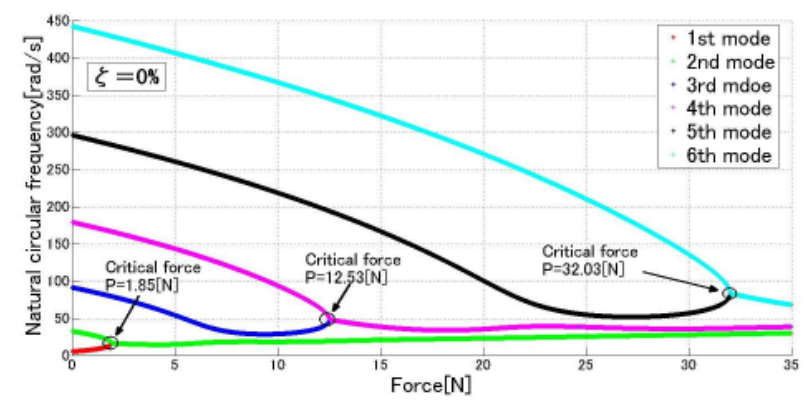

(a) No damping

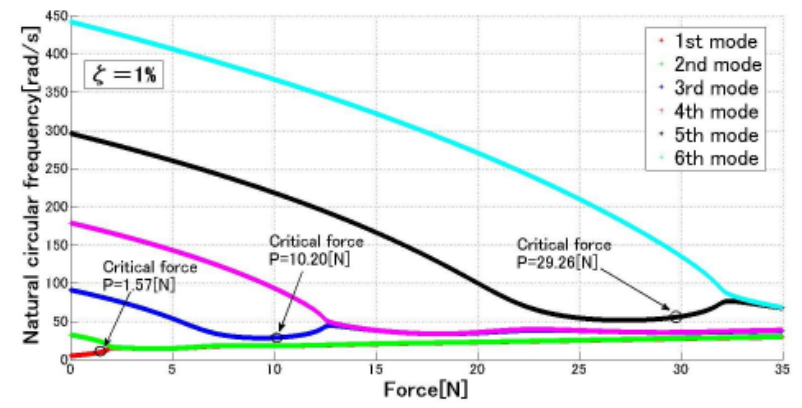

(b) $1 \%$ critical damping

Fig. 15 Dynamic stability of higher mode of a continuous model (cantilever) subjected to nonconservative distributed force

\section{$3 \cdot 7$ 連続体モデルである両端支持はり，および両端自由はりに一様分布荷重 (非保存力) が作用する場合}

図 16 (a) に両端支持はりに一様分布の非保存力（従動力）が作用する場合の根軌跡を示す. 減衰は $1 \%$ の場合 である. また, 図 16 (b) に両端自由はりに同じく一様分布の非保存力（従動力）が作用する場合の根軌跡を示寸. 同じく，減衰は $1 \%$ の場合である.

両端支持はりは，非保存力（従動力）の場合と保存力の場合とで根軌跡の相違は小さく，片持ちはりに非保 存力（従動力）が作用するときのようなフラッタは発生しない. 一方, 両端自由はりでは, 両者の相違は大きく, 保存力が作用するときはフラッタが発生しないが，非保存力（従動力）が作用寸るときはフラッタの発生が認め 
られる．弾性はりの支持条件の違いが安定性に相違をもたらすことがわかる．なお，これらについては，さらな る詳細な検討が必要と考える.

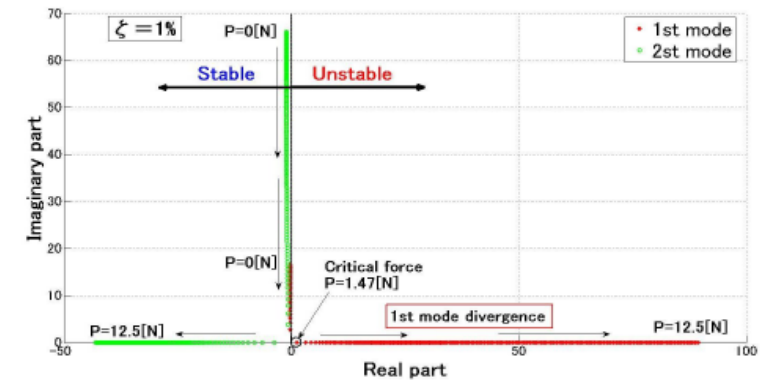

(a) simply supported beam at both ends

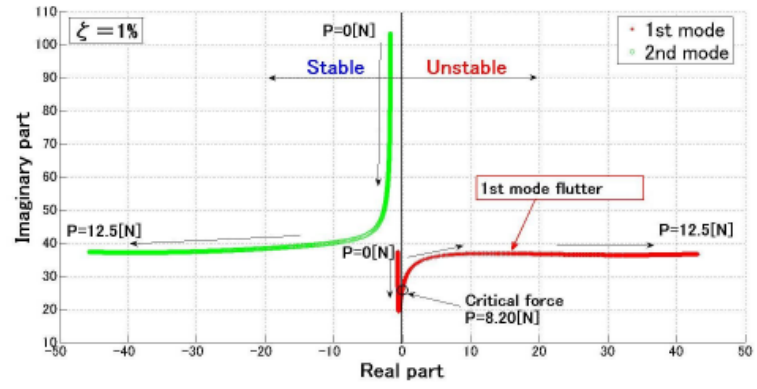

(b) free-free beam

Fig. 16 Root locus of continuous model subjected to nonconservative distributed force

\section{4. 結 語}

（1）従動力である非保存力を受ける弾性はりの動的安定性について，連続体モデルである片持ちはりが集中荷重 を受ける場合と一様分布荷重を受ける場合について数值解を提案し, 保存力と非保存力（従動力）が作用すると きの動的挙動を明確にした. 保存力の場合, 最初にダイバージェンスが現れるが，非保存力（従動力）の場合, 臨 界荷重は高くなるが，最初にフラッタが現れることを確認した.

（2）また，保存力が作用するときは，減衰は不安定挙動の臨界值に影響を与えないが，非保存力（従動力）が作 用するときは, 不安定挙動の臨界值に影響を与え, 減衰の不安定効果が認められることを確認した. また, 非減 衰系では連成モードフラッタが生じる，減衰系では単独モードフラッタが非減衰系の連成モードフラッタより低 い荷重で生じ，その後それより高い荷重で，非減衰系の連成モードフラッタに相当するモードの合体が生じるこ とを示した.

（3）分布荷重が作用する場合も，集中荷重の場合と同様の動的不安定挙動を示すことを示した.

(4) 弾性はりの支持条件の違いが安定性に影響のあることがわかった.

\section{文献}

(1) Bolotin, V. V., "Nonconservative Problems of the Theory of Elastic Stabilities, Pergamon press (1963).

(2) Ziegler, H., "Principles of Structural Stability", Blaisdell Publishing Company, A Division of Ginn and Company (1968).

(3) Leiphols H., "Stability of elastic systems", The Universities Press, Belfast, Samsom-Sijthoff, Alphen aan den Rijn (1980).

(4) 杉山吉彦, 関谷壮, “非保存的弾性系の安定問題”, 日本機械学会誌, Vol. 73, No. 620 (1970), pp.1238-1245.

(5) 本間俊雄, 登坂宣好, “積分方程式法による保存力・非保存力を受ける弾性棒の動的安定解析”, 日本機械学会論文集 A 編, Vol. 63, No. 614 (1997), pp.2180-2187.

(6) Langthjem, A. M., "Optimum Design of Cantilevered Columns Subjected to Non-conservative Loading by Rocket Thrust", Doctoral Thesis at Osaka Prefecture University (2002).

(7) Kounadis, A. N., Gantes, and C. j., Bolotin, V. V., "An Improved Energy Criterion for Dynamic Buckling of Imperfection Sensitive Nonconservative Systems", International Journal of Solids and Structures, Vol. 38 (2001), pp.7487-7500.

(8) Schmid, P. J., Langre, E. de., "Transient Growth Before Coupled-Mode Flutter", Transactions of the ASME, Journal of Applied Mechanics, Vol. 70 (2003), pp.894-901.

(9) Fazelzadeh, S. A., Kalantani, H., and Mazidi, A., "Aeroelastic Instability of Bending-Torsion Wings Containing a Mass Subjected to Follower Force", Proc. of the $9^{\text {th }}$ International Conference on Flow-Induced Vibration (2008), pp.477-482.

(10) 藤田 勝入, 後藤 彰秀, “流体力を近似した軸方向力を受けるはりの非保存的弾性安定性に関する考察”, 日本機 械学会論文集 C 編, Vol. 78, No. 789 (2012), pp.1565-1574. 